Shestakovskyi O.P., Lecturer at Sociology department, National Technical University of Ukraine «Kyiv Politechnic Institute»

\title{
ASSESSMENT OF HIV-RELATED COMPOUND STIGMA STRUCTURE IN UKRAINIAN GENERAL POPULATION
}

\begin{abstract}
HIV/AIDS stigma durably compounds with other marginalized groups' co-stigmas and bigger cleavages of social inequality (Campbell \& Deacon, 2006). While it may be considered a manifestation of the epidemics'structural drivers that were named by P. Piot (2006) among its greatest challenges, it surprisingly lacks measurement. In this article, we made partial quantitative assessment of some compound stigma layers among Ukrainian general population. We explored secondary crosssectional data of European Values Study by binary logistic regression. In terms of odd ratios, HIV/ AIDS stigma appeared to be strongly compounded with co-stigmas of injecting drug users (OR: 4,65 [95\% CI: 2,96-7,33]), homosexuals (OR: 2.89 [95\% CI: 2,21-3,78]), former convicts (OR: 2,78 [95\% CI: 2,13-3,62]) and, in peculiar, of immigrants/foreign workers (OR: 6,91 [95\% CI: 4,32-11,05]). Unacceptability of commercial sex work was moderately layered with HIV/AIDS stigma (OR: 1.08 [95\% CI: 1,00-1,16]), whereas no significant associations with unacceptability of «non-commercial» adultery or casual sex were found. In addition, holding of HIV/AIDS stigma is confounded by absence of higher education (1,55 times [95\% CI: 1,13-2,13]) and living in small settlements (OR: 1,53 [95\% CI: 1,11-2,11]) or towns with 5000-100000 population (OR: 1,51 [95\% CI: 1,09-2,09]). We interpreted it as effect of uneven distribution of knowledge about HIV among population. Associations with age and gender were statistically insignificant. Findings from the study imply importance of combating particular co-stigmas for reducing HIV-related stigma. Specifically, countermeasures to layering with stigma of immigrants have been underestimated yet, and are of potential strategic concern for Ukraine.
\end{abstract}

Keywords: HIV-related stigma; compound stigma; HIV/AIDS in Ukraine; European Values Study (EVS)

Introduction. Despite all efforts, HIV-related stigma remains one of principal challenges for effective counteraction to HIV/AIDS epidemics [1; 2]. From its inception [3], the concept of stigma essentially means an "attribute that is deeply discrediting" and turning a person into a tainted and defective one in the eyes of people around [3; 4]. With respect to HIV it erects barriers for prevention and treatment and further endangers both vulnerable groups and general population [2; 5]. Nowadays, stigmatization process is widely acknowledged not only as individual labeling and stereotyping, but also as the dependent from broader socio-structural context and related to matters of discrimination, social status, power and control $[6 ; 7 ; 8 ; 9]$.

In particular, it conduces to compound stigma [10], also referred as layered [6], double [11], dual [12] or, with reservations, symbolic [13]. It occurs when HIV/AIDS stigma intersects with attitudes to already marginalized groups, whose behavior made them more exposed to HIV (men who have sex with men [MSM], injecting drug users [IDUs] or commercial sex workers [CSWs]); vulnerable groups such as convicts or migrants; or bigger social inequalities e.g. by ethnicity, gender or class $[9 ; 12 ; 14 ; 15]$. Compound stigma seems to be the key to the epidemic structural drivers that were named by P. Piot [16] the greatest for the time being and still waiting for a solution. The most surprising is that being known from the beginning of the epidemics [17; 18] and all over the Globe [19; 
$20 ; 21 ; 22 ; 23 ; 24]$, compound stigma still lacks established measures, especially at general population level $[4 ; 10 ; 25]$.

In this study we attempted to estimate quantitatively how strong HIV/AIDS stigma is compounded with co-stigmas among Ukrainian nationals. It is essential for Ukraine because its HIVinfection rates are among the highest in Europe and Central Asia [26] and about half of the HIVpositive individuals experienced recent stigmatization and discrimination [27].

There is a certain empirical evidence in Ukraine that people living with HIV/AIDS (PLWHA) face additional compound stigma as (suspected of) being IDU, LGBT, MSM, or CSW [28; 29; 30; $31 ; 32 ; 33 ; 34]$. Stereotypes that convicts and immigrants can intensify HIV-epidemics in Ukraine were documented at least among medical workers [31], and for immigrants - in media publications and instructions of Ministry of the Inferior [34].

However, most of this evidence is fragmental; it is nationally non-representative and obtained mainly from PLWHA themselves, workers of HIV-service and experts. Moreover, compound stigma still lacks clear-cut quantitative assessments. We know about no published estimation of partial importance of possible co-stigmas and risky behaviors for holding HIV/AIDS stigma on a national scale. Such findings would help to plan national information campaigns for reducing HIV-related stigma.

Methods. Design. We carried out secondary analysis of European Values Study data [35]. EVS is a longitudinal cross-national sociological survey of general populations in European countries and territories. The data are cross-sectional and are collected via standardized personal interviews [35]. Sampling is representative for every country's resident adult population [35]. The study was to compare prevalence and dynamics of values and beliefs since 1981 [36]. Research of HIV-related stigma was evidently not its purpose.

We used only set of data collected in Ukraine during the survey in 2008. Fieldwork was held from July, 12th to October, 9 by a consortium of Social Monitoring Centre, Ukrainian Institute for Social Research after Oleksandr Yaremenko and Kiev International Institute of Sociology. We extracted the last version of the aggregated EVS dataset to date [37]. Multi-stage random sample for Ukrainian survey was designed by survey administrators. It was nationally representative for adults who are 18 years and older and resident within private households. The sample was weighted by gender and age. 1507 interviews were conducted. Mode of data collection was standardized paper-assisted personal interview in Ukrainian or Russian language (by a respondent's choice). Fieldwork was based on detailed and uniform instructions prepared by the EVS advisory groups.

The subject of our present study was Ukrainian general population, namely its nationals. Therefore, we excluded those from the dataset who were not the country's citizens. That resulted in a sample of 1495 respondents.

Variables. The dependent variable (outcome) that served as an indicator of holding HIV/AIDS stigma was unwillingness to have a PLWHA as a neighbor. One portion of independent variables consisted of unwillingness to reside near people who had drug addiction, were homosexuals, had a criminal record, and were immigrants or foreign workers. They were used as proxies for holding possibly compounded stigmas towards such social groups as IDUs, MSMs, former convicts and immigrants respectively. All these variables were measured as answers to question: «On this list there are various groups of people. Could you please sort out any that you would not like to have as neighbours?» The list included (but was not limited to) people, who were «with a criminal record», «immigrants/ foreign workers», «drug addicts», «homosexuals» and «people who have AIDS». A respondent could choose more than one group. So every group has its own dichotomous variable that was constituted by answers «mentioned» (1), that signalized about stigma, or «not mentioned» $(0)$.

Additional independent variables reflected attitudes to behaviors that are often considered deviant and risky and could layer with HIV/AIDS stigma. They were assessed as considering 
unacceptable the following things: adultery, homosexuality, casual sex, and sex work (termed as prostitution). The participants were asked «Please, tell me for each of the following statements whether you think it can always be justified, never be justified, or something in between, using this card». The statements concerned (but were not limited to) the aforementioned practices. 10-point scales were used for estimation of every particular behavior. The scales were inversed to indicate unacceptability so they varied from $1=$ «always justified» to $10=$ «never justified».

We included additional covariates as possible confounders. We explored possible associations with gender (male and female) and age (in years) as standard characteristics reported in most of the studies. It was no use of engaging race or ethnicity. Population of Ukrainian nationals is racially homogeneous; ethnic Ukrainians and Russians are very similar for our topic and made up 95,1\% of the population [38].

Tertiary education and size of a respondent's settlement were used as proxies for unequal knowledge about HIV, PLWHA and ways of HIV contraction. Possession of such knowledge is associated with less HIV-related stigma [39]. People with higher education could be better aware of HIV and ways it contracts [40; 41]. Small towns and rural areas in Ukraine still have weak capacities of HIV-service non-government organizations available; also rural youth demonstrated somewhat worse knowledge about HIV [42; 43]. We coded absence of tertiary education variable dichotomously as «present» (if responded graduated from a higher education institution) and «absent» (otherwise). Settlement size variable had three levels: villages/settlements with 5000 population and less; cities with 5000-100000 population; cities with larger population.

Analysis. Descriptive analysis was conducted by exploring tables and histograms of frequencies. We depicted socio-demographic characteristics of the sample, distributions of the outcome and independent variables and understood shares of missing values.

We began analytical results with inquiry of bivariate associations between HIV/AIDS stigma indicator on the one hand and independent variables and confounders on the other. We applied chisquare analysis (for categorical variables), independent samples t-tests (comparing means of quasiinterval variables between groups who held HIV/AIDS stigma and who did not) and scatterplots. It allowed selection of variables and their reference categories for further multivariate analysis.

To shed light on compound stigma structure and partial importance of its layers, we resorted to binary logistic regression. Logistic regression helps to estimate odd ratios of changing probability of an outcome [44]. Odd ratios indicated effect size. Their statistical significance showed that respective co-stigmas compounded, and their magnitude - partial strength of compounding in comparison with other predictors.

Logistic models were built to estimate layering of 'risky' behavior and membership in stigmatized groups. Logistic model fitting was made by forward stepwise method (likelihood ratio estimation) to include variables selection ( $p=0,05$ for entry, $p=0,01$ for removal). Contrast method for categorical covariates was either indicator (for binary predictors) or simple (for variables with more than two categories).

All the calculations were performed with SPSS 19,0 on Windows 7 (32-bit) machine.

Ethical considerations. The questionnaire and survey method were approved by EVS Council of Program Directors. Ukrainian survey was conducted with accordance to ethical norms of Sociological Association of Ukraine. The final dataset contained no information that made personal identification possible. Although the language used in the questionnaire did not correspond with present practice of naming certain social groups and practices, it seemed too hard to change wording for it damaged its comparability across countries and times. Wherever possible, we replaced terms with more conventional ones.

Results. Descriptive results. Demographic characteristics of the sample are similar to those of Ukrainian nationals' adult population. It consists of 672 males (45\% of the sample) and 823 females 
(55\%). The share of the age group of 18-24 years old is $14,0 \%$ of the sample, $25-34$ years old $18,0 \%, 35-44$ years old $-16,9 \%, 45-54$ years old $-18,5 \%, 55-64$ years old $-13,0 \%, 65$ years and older $-19,6 \%$ of the sample.

Only about one fifth $(21,8 \%)$ has completed tertiary education. Population of villages and towns with 5000 of people or less produced $34,5 \%$ of the sample, cities with 5 to 100 thousand people $28,3 \%$, bigger cities $-37,2 \%$.

The overall sample considered all «risky» behaviors in question as almost never justifiable. On average, the respondents rated them around 9 on 10-points scale of unacceptability (Figure 1 (a)). Standard errors of means were $0,04-0,06$. Some answers had noticeable shares of missing values (mainly don't-knows). In particular, they varied from 5,3\% (commercial sex work) to 7,3\% (casual sex) and 10,7\% (homosexuality).

Unwillingness to have neighbors from co-stigmatized groups is considerably more variable (Figure 1 (b)). It is very high for the addicted to drugs, somewhat less spread for MSMs and former convicts and moderate for immigrants/foreign workers. Unwillingness to reside next to PLWHA themselves was $56,5 \%$ (821 respondents). These variables had from 0,6 to $4,4 \%$ of missing values (mostly don't-knows).

(a)

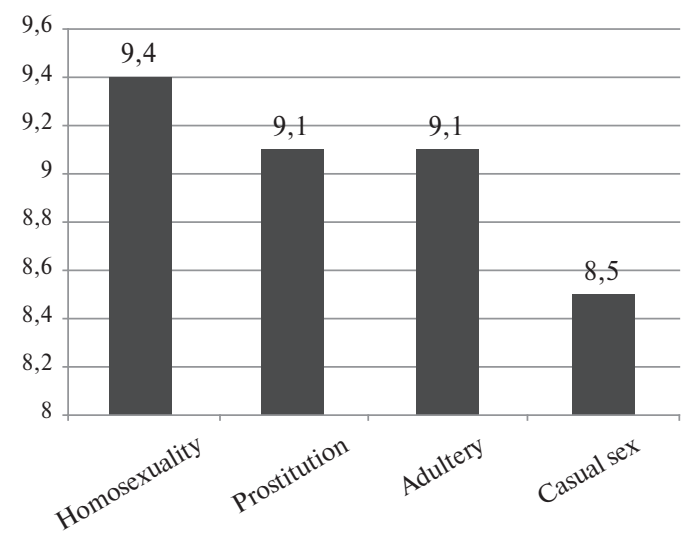

(b)

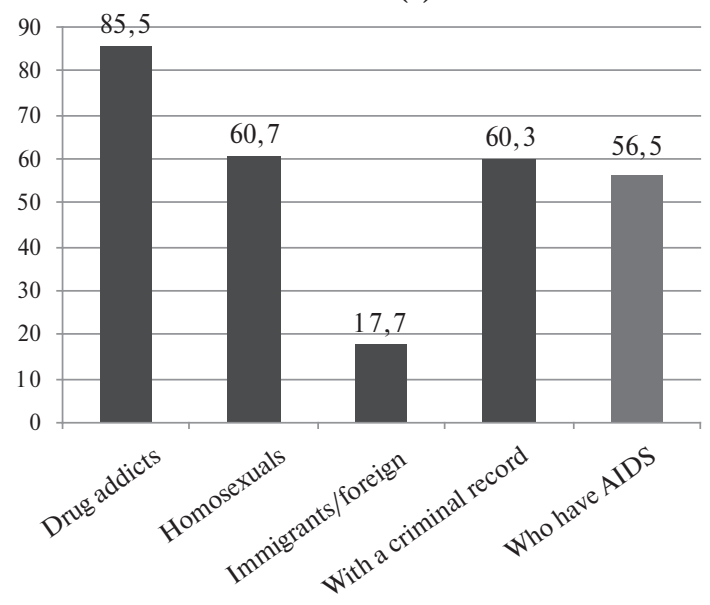

Figure 1. Distribution of negative attitudes to 'risky' behaviors and stigmatized groups among Ukrainian population (European Values Study, 2008) (a) All «risky» behaviors considered on average as almost never justified (on 10-point scale where $1=$ «always justified», $10=$ «Never justified») (b)

Unwillingness to have people from these stigmatized groups (in \% of the sample) as neighbors is more variable.

Analytic results. First, we made bivariate comparisons of predictors' distributions between those who were unwilling to reside near PLWHA and who were not (see Table 1). Unwillingness to live next to representatives of other stigmatized groups was highly correlated with the same opinion about PLWHA. Also respondents who did not wish to have PLWHA as neighbors had got significantly higher rates of homosexuality and prostitution unacceptability. Similar associations with attitudes to adultery and casual sex were on the verge of statistical significance or beyond it.

Our proxies of knowledge about HIV/AIDS were strongly associated with unwillingness to have PLWHA as neighbors (Table 1). Completing higher education and living in a big city related to lower 
prevalence of mentioning PLWHA as undesirable neighbors. Gender and age appeared statistically unrelated to our outcome'.

Table 1

Bivariate distributions related to unwillingness to have PLWHA as neighbors

\begin{tabular}{|c|c|c|c|c|c|}
\hline & & $\begin{array}{l}\text { Willing to } \\
\text { reside near } \\
\text { PLWHA } \\
(43,5 \%)\end{array}$ & $\begin{array}{l}\text { Unwilling to } \\
\text { reside near } \\
\text { PLWHA } \\
(56.5 \%)\end{array}$ & Total & p-values* \\
\hline & Factors & & & & \\
\hline \multicolumn{6}{|c|}{ Unwillingness to reside near..., \% } \\
\hline \multirow{2}{*}{ Drug addicts } & No & 82,2 & 17,8 & 100 & $<, 001$ \\
\hline & Yes & 36,9 & 63,1 & 100 & \\
\hline \multirow{2}{*}{ Homosexuals } & No & 68,0 & 32,0 & 100 & $<, 001$ \\
\hline & Yes & 27,9 & 72,1 & 100 & \\
\hline \multirow{2}{*}{ Immigrants/foreign workers } & No & 50,7 & 49,3 & 100 & $<, 001$ \\
\hline & Yes & 16,2 & 83,8 & 100 & \\
\hline \multirow{2}{*}{ People with criminal record } & No & 67,0 & 33,0 & 100 & $<, 001$ \\
\hline & Yes & 28,9 & 71,1 & 100 & \\
\hline \multicolumn{6}{|c|}{ How justifiable is... ( 1 - always justified, $10-$ never justified), means } \\
\hline & Homosexuality & 9,2 & 9,6 & 9,4 & $<, 001$ \\
\hline & Prostitution & 8,8 & 9,3 & 9,1 & $<, 001$ \\
\hline & Adultery & 9,0 & 9,2 & 9,1 & 0,139 \\
\hline & Having casual sex & 8,3 & 8,6 & 8,5 & 0,051 \\
\hline \multirow{2}{*}{ Gender, $\%$} & Male & 45,7 & 54,3 & 100 & 0,126 \\
\hline & Female & 41,7 & 58,3 & 100 & \\
\hline \multirow{2}{*}{$\begin{array}{l}\text { Absence of completed } \\
\text { tertiary education, } \%\end{array}$} & Present & 54,3 & 45,7 & 100 & $<, 001$ \\
\hline & Absent & 40,7 & 59,3 & 100 & \\
\hline \multirow{3}{*}{$\begin{array}{l}\text { Settlement population } \\
\text { (thousands of people), } \%\end{array}$} & $\begin{array}{l}5 \text { and less }(\approx \text { villages } \\
\text { and small towns) }\end{array}$ & 36,2 & 63,8 & 100 & $<, 001$ \\
\hline & $5-100$ & 40,8 & 59,2 & 100 & \\
\hline & $>100$ & 52,3 & 47,7 & 100 & \\
\hline
\end{tabular}

* P-values for $\%$ were computed as chi-square tests, and for means as independent samples $t$-tests (unequal variances).

To estimate effect size of layering co-stigmas as well as confounders, we built two logistic models (see Table 2). Model 1 assessed compounding of HIV/AIDS stigma with unacceptability of risky practices only. In Model 2 both attitudes to risky behaviors and co-stigmas of «deviant» groups were initially inputted. Attitude to adultery was not included. Whereas there were too many missing values for unacceptability of «risky» behavior, we replaced them by the variables' means before inputting into models. Otherwise we would have to omit 20 to $25 \%$ of the sample. Absence of tertiary education and settlement size were also included in both models. Reference categories were presence of tertiary education and cities with more than 100000 population.

Model 1 showed moderate associations between unacceptability of two behaviors and reluctance to have PLWHA as neighbors. Increase of the former in 1 point raises odd ratios to be unwilling in $1,09$ [95\% CI: $1,01-1,18]$ or 1,07 [95\% CI: 1,01-1,14] for homosexuality and commercial sex work

\footnotetext{
${ }^{1}$ Graphic analysis of possible associations between age and unwillingness to reside next to PLWHA also displayed no significant trend or visibly distinctive clusters.
} 
respectively. Although these figures might be contested for low values of unacceptability for the latter were rarely observed in the sample.

Model 2 demonstrated considerably ampler associations of the outcome and reluctance to live next to people from other stigmatized groups. The highest odds ratios were revealed by negative attitudes towards immigrants/foreign workers (OR: 6,91 [95\% CI: 4,32-11,05]) and IDUs (OR: 4,65 [95\% CI: 2,96-7,33]). Odd ratios for unwilling to dwell in a neighborhood with homosexuals (OR: 2,89 [95\% CI: 2,21-3,78]) and people with criminal record (OR: 2,78 [95\% CI: 2,13-3,62]) were somewhat lower. They were even smaller (with $95 \%$ probability) than odd ratio for immigrant stigma. Unacceptability of commercial sex work kept association with HIV/AIDS stigma indicator intact (OR: 1,08 [95\% CI: 1,00-1,16]) while similar opinion on homosexuality became statistically insignificant. Both models rejected having casual sex as unimportant.

Two confounders had roughly the same moderate odd ratios in both models. E.g., in Model 2 absence of completed tertiary education raised the odds of odds to be unwilling to reside near PLWA 1,55 times [95\% CI: 1,13-2,13]. Living either in a small settlement or a settlement with a population of 5 to 100 thousands also predicted higher rates of the outcome in contrast to bigger cities (OR: 1,53 [95\% CI: 1,11-2,11] and OR: 1,51 [95\% CI: 1,09-2,09] respectively). According to CIs, the confounders had weaker correlations with reluctance to have PLWHA as neighbors than unwillingness with respect to almost all other groups. Compared with unacceptability of «risky» behavior, however, they hardly had less relation to the outcome.

Table 2

Logistic regression models. Outcome is unwillingness to reside near PLWA

( 0 = willing, $1=$ unwilling)

\begin{tabular}{|c|c|c|c|c|c|c|}
\hline & \multicolumn{3}{|c|}{ Model 1} & \multicolumn{3}{|c|}{ Model 2} \\
\hline & \multirow{2}{*}{ OR } & \multicolumn{2}{|c|}{$95,0 \%$ C.I. for OR } & \multirow{2}{*}{ OR } & \multicolumn{2}{|c|}{$95,0 \%$ C.I. for OR } \\
\hline & & Lower & Upper & & Lower & Upper \\
\hline \multicolumn{7}{|l|}{ Unacceptability of... (10-point scales) } \\
\hline Homosexuality & 1,09 & 1,01 & 1,18 & - & - & - \\
\hline Prostitution & 1,07 & 1,01 & 1,14 & 1,08 & 1,00 & 1,16 \\
\hline Having casual sex & - & - & - & - & - & - \\
\hline \multicolumn{7}{|l|}{ Unwillingness to reside near... (1=unwilling) } \\
\hline Drug addicts & & & & 4,65 & 2,96 & 7,33 \\
\hline Homosexuals & & & & 2,89 & 2,21 & 3,78 \\
\hline Immigrants/foreign workers & & & & 6,91 & 4,32 & 11,05 \\
\hline People with criminal record & & & & 2,78 & 2,13 & 3,62 \\
\hline $\begin{array}{l}\text { Absence of completed tertiary education ( } 1 \\
=\text { absent) }\end{array}$ & 1,44 & 1,11 & 1,87 & 1,55 & 1,13 & 2,13 \\
\hline \multicolumn{7}{|l|}{ Settlement population } \\
\hline 5000 and less (villages and small town) & 1,62 & 1,25 & 2,10 & 1,53 & 1,11 & 2,11 \\
\hline $5000-100000$ & 1,42 & 1,09 & 1,85 & 1,51 & 1,09 & 2,09 \\
\hline$>100000$ & Ref. & Ref. & Ref. & Ref. & Ref. & Ref. \\
\hline Constant & 0,23 & & & 0,30 & & \\
\hline Nagelkerke pseudo-R2 & 0,05 & 0,38 & & & & \\
\hline Effective sample size ( $\%$ of the sample) & $\begin{array}{c}1451 \\
(97,0 \%)\end{array}$ & $\begin{array}{c}1344 \\
(89,8 \%)\end{array}$ & & & & \\
\hline
\end{tabular}


Discussion. The study clearly showed that HIV/AIDS stigma was strongly compounded with stigmatizing such groups as IDUs, MSM, former convicts and immigrants/foreign workers in the consciousness of Ukrainian nationals. Whereas the first three groups were expected, such strong association of HIV/AIDS with immigrants was quite impressive. Its effect size appeared to exceed those for MSM and convicts.

HIV-related stigma was moderately layered with personal unacceptability of homosexuality and prostitution. Interesting, that personal attitude to other heterosexual promiscuous behaviors did not relate to stigma despite they were declared as unjustified as almost the previous ones. In addition, layering with «risky» behaviors was noticeably lower than with membership in stigmatized groups. Perhaps, a personal opinion on unacceptability of these behaviors did not inevitably imply stigmatization of everyone who could practice them from time to time - at least to a degree of not willing to have them as neighbors. It was also confirmed that prevalence of HIV/AIDS stigma was affected by uneven spread of knowledge about HIV-infection and PLWHA by education and different territorial coverage by interventions. Its effect size was comparable with that of attitude to behaviors.

In terms of interventions, our findings emphasize necessity of struggle against stigmas of IDUs, MSM, convicts, and commercial sex work among Ukrainian general population, and against their perception as an original source of HIV. Substantive attention to disentangling HIV/AIDS stigma from prejudgment to immigrants is of strategic importance. It did not matter much because Ukraine does not have considerable immigration at the moment. Therefore, intense programs that related to them have been practically absent. But if immigration rates rise in future, it could seriously hinder reduction of HIV-related stigma and tackling the epidemics in general. Good news is that compounding HIV/ AIDS with «non-commercial» promiscuous behavior does not seem to be a problem. However, it means necessity of further propagating safe sex practices if to bear in mind their insufficient popularity [43] and prevailing of sexual transmission of HIV since 2008 [45]. Finally, our results imply that rising awareness campaigns should be broadened in villages and small towns.

The results are consistent with previous Ukrainian findings that PLWHA are oftener face stigma and discrimination if they are also IDUs, MSM or former prisoners, although we did not obtain comparable results for commercial sex work [27; 29]. It can be explained by shortcomings of our data.

Yet our study has a number of crucial drawbacks, preconditioned mostly by the limitations of secondary data. Although we provided relative weights for available stigma layers, it was principally impossible to define their share in $\%$ of total stigma. To solve that, we would have needed factorial design of outcome and main independent variables [21;46]. Causation direction for stigma layers remains also discussable. Binary variables did not let deep enough exploration of HIV/AIDS and related stigmas that is proved to have multidimensional nature [1]. Moreover, we needed similar indicators of group stigma for CSW or consuming opiates in list of unjustified behaviors. Difference of associations' strength for stigmatized groups and behaviors could be artificially exaggerated by two factors. First, the groups were in the same question list as the PLWHA. Second, the question about acceptability of «risky» behaviors seemed to reflect social desirability to greater extent if to consider small variance and bigger share of missing values in answers. Absence of direct indicator of knowledge about HIV, PLWHA and modes of virus transmission made us resort to disputable proxies. Last, but not the least, the data are almost 5 years old, and one could question how good they correspond with current situation.

Nevertheless, this criticism does not contradict our central point about the structure of the wide-spread HIV/AIDS compounded stigma in Ukraine.

Conclusion. Coping with HIV/AIDS stigma in Ukraine (and elsewhere) is hardly possible without combating particular layered co-stigmas. Despite our study limitations, its results confirm significant stigma compounding with stigmas of IDUs, MSM, convicts, commercial sex work, and 
(what was less expected) immigrants/foreign workers. It must help to build more realistic national policies for tackling HIV-related stigma, expand their points of application, and find new ways to unbind perception of HIV/AIDS from preexisting prejudice and inequalities.

Acknowledgements. This paper is an outgrowth of participation in HIV Research Workshop that was held by New York State International Training and Research Program (NYS-ITRP) in Kyiv, Ukraine in 2011-2013. The author owes much to its fruitful discussions and expresses particular thanks to Michael Joseph, David Odegaard, Robert Kaplan and Danielle Ompad.

Research for this paper was also supported in part by the Carnegie Research Fellowship Program, which is administered by the National Council for Eurasian and East European Research (NCEEER). The opinions expressed herein are the author's own and do not necessarily express the views of either the Carnegie Corporation of New York or NCEEER.

\section{References}

1. Earnshaw V.A., Chaudoir S.R. From conceptualizing to measuring HIV stigma: a review of HIV stigma mechanism measures. AIDS and Behavior, 2009, No. 13 (6), p. 1160-1177.

2. Kaplan A.H., Scheyett A., Golin C.E. HIV and stigma: Analysis and research program. Current HIV/AIDS Reports, 2005, No. 2 (4), p. 184-188.

3. Goffman E. Stigma: Notes on the management of spoiled identity. Englewood Cliffs, NJ: PrenticeHall, 1963.

4. Mahajan A.P., Sayles J.N., Patel V.A., Remien R.H., Ortiz D., Szekeres G., Coates T.J. Stigma in the HIV/AIDS epidemic: A review of the literature and recommendations for the way forward. AIDS (London, England), 2008, No. 22 (Suppl 2), p. 67-79. DOI:10.1097/01. aids.0000327438.13291.62

5. Stein J. HIV/AIDS stigma: The latest dirty secret. African Journal of AIDS Research, 2003, No. 2 (2), p. 95-101. DOI:10.2989/16085906.2003.9626564

6. Campbell C., Deacon H. Unravelling the contexts of stigma: from internalisation to resistance to change. Journal of Community \& Applied Social Psychology, 2006, No. 16 (6), p. 411-417.

7. Castro A., Farmer P. Understanding and addressing AIDS-related stigma: from anthropological theory to clinical practice in Haiti. Journal Information, 2005, No. 95 (1), available at: http://ajph. aphapublications.org/doi/pdf/10.2105/AJPH.2003.028563

8. Link B.G., Phelan J.C. Conceptualizing stigma. Annual review of Sociology, 2001, p. 363-385.

9. Parker R., Aggleton P. HIV and AIDS-related stigma and discrimination: a conceptual framework and implications for action. Social science \& medicine, 2003, No. 57 (1), p. 13-24.

10. Nyblade L.C. Measuring HIV stigma: Existing knowledge and gaps. Psychology, Health \& Medicine, 2006, No. 11 (3), p. 335-345. DOI:10.1080/13548500600595178

11. Demchenko I.L., Kostenko K.S., Grigorenko Y.M., Parkhomenko Z.V., Galusyan Y.M., Nizova N.M., ... Salabaj N.V. Ukraine: Monitoring the UNGASS-AIDS goals on sexual and reproductive health. Analytical Survey. Kyiv, 2008, available at: http://icaso.org/resources/shadow_report_ UNGAS_Ukraine_eng.pdf [in Ukrainian]

12. Mawar N., Sahay S., Pandit A., Mahajan U. The third phase of HIV pandemic: social consequences of HIV/AIDS stigma \& discrimination \& future needs. Indian Journal of Medical Research, 2005, No. 122 (6), p. 471.

13. Herek G.M. Thinking about AIDS and stigma: A psychologist's perspective. The Journal of Law, Medicine \& Ethics, 2002, No. 30 (4), p. 594-607.

14. Deacon H. Towards a sustainable theory of health-related stigma: lessons from the HIV/AIDS literature. Journal of Community \& Applied Social Psychology, 2006, No. 16 (6), p. 418-425. DOI:10.1002/casp.900

15. Herek G.M. AIDS and stigma. American Behavioral Scientist, 1999, No. 42 (7), p. 1106-1116. 
16. Piot P. AIDS: from crisis management to sustained strategic response. Lancet, 2006, No. 368 (9534), p. 526-530.

17. Conrad P. The social meaning of AIDS. Policymaking Under Adversity, 1986, No. 17 (1), p. 75.

18. Herek G.M., Glunt E.K. An epidemic of stigma: Public reactions to AIDS. American Psychologist, 1988, No. 43 (11), p. 886.

19. Anderson M., Elam G., Gerver S., Solarin I., Fenton K., Easterbrook P. HIV/AIDS-related stigma and discrimination: Accounts of HIV-positive Caribbean people in the United Kingdom. Social Science \& Medicine, 2008, No. 67 (5), pp. 790-798.

20. Bharat S. A systematic review of HIV/AIDS-related stigma and discrimination in India: Current understanding and future needs. SAHARA-J: Journal of Social Aspects of HIV/AIDS, 2011, No. 8 (3), p. 138-149. DOI:10.1080/17290376.2011.9724996

21. Chan K.Y., Yang Y., Zhang K.-L., Reidpath D.D. Disentangling the stigma of HIV/AIDS from the stigmas of drugs use, commercial sex and commercial blood donation - a factorial survey of medical students in China. BMC Public Health, 2007, No. 7 (1), p. 280. DOI:10.1186/1471-2458$7-280$

22. Dodds C. HIV-related stigma in England: experiences of gay men and heterosexual African migrants living with HIV. Journal of Community \& Applied Social Psychology, 2006, No. 16 (6), p. 472-480.

23. Kasapoğlu A., Kuş E. The role of gender in the stigmatization of people living with HIV/AIDS in Turkey. Journal of Gender Studies, 2008, No. 17 (4), p. 359-368. DOI:10.1080/09589230802473390

24. Nyblade L., Pande R., Mathur S., MacQuarrie K., Kidd R., Banteyerga H., ... Bond V. Disentangling HIV and AIDS stigma in Ethiopia, Tanzania, and Zambia. International Center for Research on Women Washington, DC, 2003, available at: http://www.rti.org/pubs/nyblade_psg. pdf

25. Sengupta S., Banks B., Jonas D., Miles M.S., Smith G.C. HIV Interventions to Reduce HIV/AIDS Stigma: A Systematic Review. AIDS and Behavior, 2011, No. 15 (6), p. 1075-1087. DOI:10.1007/ s10461-010-9847-0

26. Joint United Nations Programme on HIV/AIDS. Global report UNAIDS report on the global AIDS epidemic: 2012. [Geneva]: UNAIDS, 2012, available at: http://www.unaids.org/en/media/ unaids/contentassets/documents/epidemiology/2012/gr2012/20121120_UNAIDS_Global_ Report_2012_en.pdf

27. Demchenko I.L., Sosidko T.I., Kostyuchok M.M., Belonosova N.A., Salabai N.V., Hvozdetska N.V., ... Poliantsev P.I. The People Living with HIV Stigma Index: Analytical Report Based on Research Findings. (Analytical). Kyiv, 2011, available at: http://www.stigmaindex.org/download. php?id=100 [in Ukrainian]

28. Barcal K., Schumacher J.E., Dumchev K., Moroz L.V. A situational picture of HIV/AIDS and injection drug use in Vinnitsya, Ukraine. Harm reduction journal, 2005, No. 2 (1), p. 16. DOI:10.1186/1477-7517-2-16

29. Bolshov E., Davis O., Kharchenko N., Oksamytna S., Poholok O., Sakhno J., ... Zhmurko O. Vulnerability Assessment of People Living With HIV (PLHIV) in Ukraine (p. 98). Kyiv: Kiev International Institute of Sociology, UNDP, 2008, available at: http://europeandcis.undp. org/rhdr.aids2008/report/hiv_ukraine_en.pdf

30. Chase E., Aggleton P. Stigma, HIV/AIIDS and prevention of mother-to-child transmission: A pilot study in Zambia, India, Ukraine and Burkina Faso (p. 41). London: The Panos Institute: United Nations Children's Fund (UNICEF), 2001, available at: http://www.unicef.org/evaldatabase/ index_14340.html

31. Health Policy Initiative, Task I, \& The USAID. Stigmatization and discrimination of HIV-positive people by providers of general medical services in Ukraine. Washington, DC: 2007, available at: http://www.pdf.usaid.gov/pdf_docs/PNADM170.pdf. 
32. Mimiaga M.J., Safren S.A., Dvoryak S., Reisner S.L., Needle R., Woody G. "We fear the police, and the police fear us": structural and individual barriers and facilitators to HIV medication adherence among injection drug users in Kiev, Ukraine. AIDS care, 2010, No. 22 (11), p. 13051313. DOI:10.1080/09540121003758515

33. Spicer N., Bogdan D., Brugha R., Harmer A., Murzalieva G., Semigina T. 'It's risky to walk in the city with syringes': understanding access to HIV/AIDS services for injecting drug users in the former Soviet Union countries of Ukraine and Kyrgyzstan. Globalization and Health, 2011, Vol 7:22.

34. Zakharov E. (eds.). Prava liudyny v Ukraini - 2012. Dopovid pravozakhysnykh organizatsii [Human Rights in Ukraine 2012. Human rights organizations report] Kharkiv: Kharkiv Human Rights Protection Group, 2013, p. 560, available at: http://khpg.org/files/docs/1362676111.pdf

35. European Values Study \& GESIS - Leibniz Institute for the Social Sciences (2011): EVS 1981-2008 Variable Report. GESIS-Variable Reports 2011/10, available at: http://www. europeanvaluesstudy.eu/.

36. Halman L., Sieben I., van Zundert M. Atlas of European values: Trends and traditions at the turn of the century. Koninklijke Brill, 2012.

37. European Values Study European Values Study 1981-2008, Longitudinal Data File. GESIS Data Archive, Cologne, Germany, ZA4804 Data File Version 1.0.0 (2011-04-30) DOI:10.4232/1.14804.

38. State Statistics Committee of Ukraine. (2004). All-Ukrainain Population Census 2001 | English version | Results | General results of the census | National composition of population: Retrieved April 20, 2013, available at: http://2001.ukrcensus.gov.ua/eng/results/general/nationality/

39. Pulerwitz J., Michaelis A., Weiss E., Brown L., Mahendra V. Reducing HIV-related stigma: lessons learned from Horizons research and programs. Public health reports (Washington, D.C.: 1974), 2010, No. 125 (2), p. 272-281.

40. Feyissa G.T., Abebe L., Girma E., Woldie M. Validation of an HIV-related stigma scale among health care providers in a resource-poor Ethiopian setting. Journal of Multidisciplinary Healthcare, 2012, No. 5, p. 97-113. DOI:10.2147/JMDH.S29789

41. Schenker I.I. HIV/AIDS literacy: an essential component in education for all. Paper commissioned for the EFA Global Monitoring Report, 2006, available at: http://hivaidsclearinghouse.unesco.org/ search/resources/HIV-literacy.pdf

42. Bega A. HIV/AIDS Policy in Ukraine: A Civil Society Perspective. Open Society Foundations, 2007, p. 68. Open Society Institute, New York, available at: http://www.opensocietyfoundations.org/ sites/default/files/ukraine_20071015.pdf

43. Ministry of Health of Ukraine. Ukraine Harmonized AIDS Response Progress Report. Kyiv, 2012, available at: http://www.unaids.org/en/dataanalysis/knowyourresponse/countryprogressreports/ 2012countries/ce_UA_Narrative_Report\%5B1\%5D.pdf

44. Shalizi C.R. Advanced Data Analysis from an Elementary Point of View. Manuscript submitted for publication, 2013, available at: http://www.stat.cmu.edu/ cshalizi/ADAfaEPoV/ADAfaEPoV. pdf

45. Nizova N.M., Shcherbynska A.M., Gaiovych Y.V., Bochkova L.V., Riabokon S.V., Koliada O.Y., ... Kobyshcha Y.V. VIL-infektsiia $v$ Ukraini. Informatsiinyi biuleten [HIV-infection in Ukraine Newsletter]. № 30. Kyiv, 2011, available at: http://www.unaids.org.ua/files/Information_ Bulletin-37_Ukr.docx

46. Reidpath D.D., Chan K.Y. A method for the quantitative analysis of the layering of HIV-related stigma. AIDS care, 2005, No. 17 (4), p. 425-432.

Отримано 22.09.15 
Шестаковський О.П., викладач кафедри соціології, Національний технічний університет України «Київський політехнічний інститут»

\section{ОЦІНКА СТРУКТУРИ СТИГМ, СПОЛУЧЕНИХ ЗІ СТИГМАМИ ЩОДО ЛЖВ СЕРЕД НАСЕЛЕННЯ УКРАЇНИ}

Стигма щодо ЛЖВ стабільно сполучається зі стигмами щодо інших маргіналізованих груп. Хоча вона може вважатися одним з найсерйозніших викликів епідемії, існує мало праць, де б вимірювалася така складена стигма. У статті проведено кількісну оцінку зв'язку між складовими стигми серед населення України на підставі даних Європейського дослідження цінностей 2008 р. Стигма щодо ЛЖВ виявилася значущо сполученою зі стигмами щодо CIH, гомосексуалів, колишніх ув'язнених $i$, особливо, іммігрантів/іноземних робітників. Неприйнятність комериійної секс-роботи була помірковано сполучена зі стигмою щодо ЛЖВ, тоді як не було знайдено значущих зв'язків зі ставленням до адюльтеру чи випадкового сексу. Крім того, підтримка стигми щодо ЛЖВ пов'язана з частішою відсутністю вищої освіти серед респондентів і проживанням у невеликих містах і поселеннях, що проінтерпретовано як наслідок нерівномірного розподілу знання про ВІЛ-інфекцію/СНІД серед населення. Результати дослідження показують важливість боротьби з конкретними сполученими стигмами для зменшення стигми щодо ЛЖВ. Зокрема, важливість контрзаходів проти ї̈ сполучення зі стигмою щодо іммігрантів досі недооцінювалася, $i$ потенційно є стратегічно важливою для України.

Ключові слова: стигма щодо ЛЖВ, складена стигма, ВІЛ-інфекція/СНІД в Україні, Європейське дослідження цінностей (EVS).

Шестаковский А.П., преподаватель кафедры социологии, Национальный технический университет Украины «Киевский политехнический институт»

\section{ОЦЕНКА СТРУКТУРЫ СТИГМ, СОВМЕЩЕННЫХ СО СТИГМАМИ ОТНОСИТЕЛЬНО ЛЖВ СРЕДИ НАСЕЛЕНИЯ УКРАИНЫ}

Стигма относительно ЛЖВ стабильно совмещается со стигмами по отношению к другим маргинализированным группам. Хотя она может считаться одним из наиболее серьезных вызовов эпидемии, существует мало работ, где бы измерялась такая составная стигма. $B$ статье проведена количественная оценка связи между составляющими стигмы среди населения Украины на основе данных Европейского исследования ценностей 2008 г. Стигма по отношению к ЛЖВ оказалась статистически значимо совмещённой со стигмами относительно ПИН, гомосексуалов, бывших заключенных и, особенно, иммигрантов/иностранных работников. Неприемлемость коммерческой секс-работы была умеренно совмещена со стигмой относительно ЛЖВ, в то время как не найдено значимой связи с отношением к адюльтеру или случайному сексу. Кроме того, поддержка стигмы относительно ЛЖВ была связана с более частым отсутствием высшего образования среди респондентов и проживанием в небольших городах и поселениях, что было проинтерпретировано как следствие неравномерного распределения знания о ВИЧ-инфекции/СПИДе среди населения. Результаты исследования показывают важность борьбы с конкретными совмещенными стигмами для уменьшения стигмы относительно ЛЖВ. В частности, важность контрмер против ее совмещения со стигмой относительно иммигрантов до сих пор недооценивалась, и потенциально является стратегически актуальной для Украины.

Ключевые слова: стигма относительно ЛЖВ, составная стигма, ВИЧ-инфекция/СПИД в Украине, Европейское исследование ценностей (EVS). 